\title{
GacA, the Response Regulator of a Two-Component System, Acts as a Master Regulator in Pseudomonas syringae pv. tomato DC3000 by Controlling Regulatory RNA, Transcriptional Activators, and Alternate Sigma Factors
}

\author{
Asita Chatterjee, ${ }^{1}$ Yaya Cui, ${ }^{1}$ Hailian Yang, ${ }^{1}$ Alan Collmer, ${ }^{2}$ James R. Alfano, ${ }^{3}$ and Arun K. Chatterjee ${ }^{1}$ \\ ${ }^{1}$ Department of Plant Microbiology and Pathology, University of Missouri, Columbia, MO, U.S.A.; ${ }^{2}$ Department of Plant \\ Pathology, Cornell University, Ithaca, NY, U.S.A.; and ${ }^{3}$ Plant Science Initiative and the Department of Plant Pathology, \\ University of Nebraska, Lincoln, NE, U.S.A.
}

Submitted 11 April 2003. Accepted 1 August 2003.

Concerted investigations of factors affecting host-pathogen interactions are now possible with the model plant Arabidopsis thaliana and its model pathogen Pseudomonas syringae pv. tomato $\mathrm{DC} 3000$, as their whole genome sequences have become available. As a prelude to analysis of the regulatory genes and their targets, we have focused on GacA, the response regulator of a two-component system. The DC3000 gene was cloned by testing for the reversal of phenotypes of an Erwinia $\mathrm{GacA}^{-}$mutant. A $\mathrm{GacA}^{-}$ mutant of DC3000 constructed by marker exchange produces much-reduced levels of transcripts of three alternate sigma factors: HrpL, required for the production of effector proteins and their translocation via the type III secretion system; RpoS, required for stress responses and secondary metabolite production; and $\mathrm{RpoN}$, required for an assortment of metabolic processes and expression of $h r p L$. GacA deficiency also reduces the expression of $h r p R$ and $h r p S$, which specify enhancer-binding proteins of the NtrC family required for $h r p L$ transcription; ahlI and $a h l R$, the genes for quorum sensing signal; salA, a regulatory gene known to control virulence; CorS, a sensor kinase; CorR, the cognate response regulator that controls coronatine biosynthetic genes; and $r s m B$ and $r s m Z$, which specify untranslatable regulatory RNA species. gacA expression itself is regulated by environmental conditions in DC3000, since transcript levels are affected by growth phase and media composition. The observations that high levels of gacA RNA occur in the hrp-inducing medium and GacA deficiency reduces the levels of rpoS expression implicate an important role of GacA in stress responses of $\mathrm{DC} 3000$. Consistent with the effects on hrpL expression, the $\mathrm{GacA}^{-}$mutant produces lower levels of transcripts of avr, hrp, and hop genes controlled by HrpL. In addition, GacA deficiency results in reduced levels of transcripts of several HrpL-independent genes. As would be expected, these effects on gene expression cause drastic changes in bacterial behavior: virulence towards $A$. thaliana and tomato; multiplication in planta; efficiency of the induction of the hypersensitive reaction (HR); production of pigment and $N$-acyl-homoserine lac-

Corresponding author: A. Chatterjee; Telephone: 573882 1892; Fax: 573882 0588; E-mail: chatterjeea@missouri.edu tone (AHL), the presumed quorum-sensing signal; and swarming motility. Our findings establish that GacA, located at the top in a regulatory cascade in DC3000, functions as a central regulator by controlling an assortment of transcriptional and posttranscriptional factors.

Of the plethora of regulators identified in pathogenic and environmentally significant bacteria, members of the two-component system are perfectly suited to sense and recognize environmental cues and signals and to transduce the information to transcriptional factors, which could, in turn, activate the expression of one or several genes whose production allows the bacterium to rapidly adjust to environmental conditions. Such systems generally comprise two proteins: a sensor kinase that perceives a signal or cue, autophosphorylates, and then activates its partner, a protein known as a response regulator (RR). The activated RR functions as the transcriptional activator of one or more genes. A two-component system comprising GacS and GacA or their homologs has been found in numerous bacteria, including plant pathogens (Heeb and Haas 2001). In this case, GacS is the putative sensor kinase and GacA is the RR. This system has been found to control an array of phenotypes, including pathogenicity, plant growth promoting capability, survival, production of secondary metabolites such as antibiotics, quorum sensing signals and toxins, motility, biofilm formation, secretion systems, extracellular polysaccharides, and secreted proteins and enzymes (Blumer et al. 1999; Bull et al. 2001; Castañeda et al. 2001; Chancey et al. 1999 2002; Cui et al. 2001; Duffy and Défago 2000; Heeb and Haas 2001; Laville et al. 1992; Natsch et al. 1994; Parkins et al. 2001; Pessi and Haas 2001; Rich et al. 1994; Saleh and Glick 2001; Whistler et al. 2000; Willis et al. 1990).

Despite extensive studies of phenotypic effects of $\mathrm{GacS} / \mathrm{GacA}$ in various bacteria, little is known about the modes of action of the two components, the nature of the signals perceived by GacS, regulation of GacA production and modulation of GacA function, the primary targets of GacA, and the inventory of the genes and their products that are controlled by GacA. To alleviate these deficiencies, we have chosen to study the GacS/GacA system of the model pathogen Pseudomonas syringae pv. tomato DC3000, which infects tomato as well as Arabidopsis thaliana. In this report, we present evidence that 
$\mathrm{GacA}$ is a master regulator that controls several alternate sigma factors, genes for quorum sensing signal and regulatory RNA and protein species. Our finding that GacA controls HrpLdependent genes required for virulence as well as regulators of the chlorosis-inducing toxin coronatine is consistent with its role as a global regulator of virulence determinants. Moreover, the effects of GacA on quorum-sensing signal and alternate sigma factors have important ramifications in ecological fitness of this plant pathogen. We also document for the first time that GacA production is regulated in DC 3000 by growth phase and stress conditions.

Studies in Erwinia carotovora (Chatterjee et al. 1995; Cui et al. 1995), Escherichia coli (Romeo 1998), Pseudomonas aeruginosa (Pessi et al. 2001), and P. fluorescens (Blumer et al. 2000; Heeb et al. 2002) have revealed that posttranscriptional regulation mediated by the RsmA-rsmB pair (CsrA and $\operatorname{csr} B$ in $E$. coli) plays a critical role in gene expression. RsmA is a small RNA-binding protein that acts by repressing translation and by promoting decay of mRNA species. $r s m B$ specifies an untranslated regulatory RNA that binds RsmA and neutralizes its negative regulatory effect. It also has become apparent that GacS and GacA control rsmB expression, and genetic data demonstrate that this regulation is, in fact, responsible for the GacA effect on various phenotypes in $\mathrm{Er}$ winia carotovora (Cui et al. 2001). We have determined the presence of $r \operatorname{sm} A, r \operatorname{smB}$, and $r \operatorname{sm} Z$ genes in DC3000, and our findings with cloned genes have revealed that several RsmA species function as negative regulators and that $\operatorname{rsmB}$ RNA and $r s m Z$ RNA act as positive regulators (A. Chatterjee, unpublished data). We document here that GacA positively controls $r s m B$ and rsmZ RNA production in DC3000. Based on the findings reported here, we present a model depicting the GacA regulon of DC3000.

\section{RESULTS}

\section{Sequence analysis of gac $_{D C 3000}$.}

Analysis of the whole genome sequence of $P$. syringae pv. tomato DC3000 revealed the presence of a homolog of gacA comprising a 666-bp open reading frame that could encode a putative $\mathrm{GacA}_{\mathrm{DC} 3000}$ polypeptide of $24.2 \mathrm{kDa}$ with 222 amino acid residues. A Blast search revealed that $\mathrm{GacA}_{\mathrm{DC} 3000}$ shares high homology with GacA of $P$. syringae pv. syringae $(92 \%$ identity and 93\% similarity) (accession number A55538), GacA of $P$. fluorescens (85\% identity and $89 \%$ similarity) (accession number BAB41136.1), GacA of P. aeruginosa (84\% identity and 89\% similarity) (accession number NP_251276.1), and GacA of P. viridiflava (91\% identity and $93 \%$ similarity) (accession number AAB38979.1). The results of a Prosite scan of $\mathrm{GacA}_{\mathrm{DC} 3000}$ revealed a putative response regulatory domain located between amino acid residues 11 and 127, a putative HTH motif of the LuxR family located between residues 172 and 199, and seven putative protein kinase $\mathrm{C}$ phosphorylation sites. Domains and motif are conserved in GacA species of several other bacteria (Heeb and Haas 2001). Northern blot analysis using an internal fragment of $g a c A_{D C 3000}$ (polymerase chain reaction [PCR] product) as a probe revealed an approximately $0.75-\mathrm{kb}$ transcript in DC3000 (Fig. 1A, lane 1), indicating that $g_{a c} A_{D C 3000}$ comprises a single gene operon. As would be expected, the $\mathrm{GacA}_{\mathrm{DC} 3000}{ }^{-}$mutant AC811, constructed by marker exchange, does not produce this RNA species (Fig. 1A, lane 2). Sequence analysis of pAKC1112 (inactivated gacA plasmid) (Table 1) revealed that the mini-Tn5-Km insertion is located at $361 \mathrm{nt}$ from the translational start site. The transcriptional start site of $g a c A_{D C 3000}$ was located by $\mathrm{S} 1$ nuclease protection analysis to the $\mathrm{C}$ residue at base -79 relative to the translational start site (data not shown).
Media and cell density effects on expression of gacA.

To examine the effects of media and growth rate on the expression of $g a c A_{D C 3000}$, total RNA samples were extracted from DC3000 grown in rich medium (King's B $[\mathrm{KB}]$ ) at Klett values of 100,200 , and 300 or grown in KB medium to a Klett value of 100 and transferred into hrp-inducing medium (IM) and incubated for an additional $0.5,1,1.5$, and 2 h. Northern blot analysis with $g a c A_{D C 3000}$ probe (Fig.1B) revealed that: i) the levels of $g a c A_{D C 3000}$ transcript were higher at higher cell densities in $\mathrm{KB}$ medium and ii) the $g a c A_{D C 3000}$ transcript levels were higher when incubated in IM than in $\mathrm{KB}$ medium, and it reached the highest level after $2 \mathrm{~h}$ incubation in IM.

\section{GacA positively controls the production of AHL.}

Search of the DC3000 genome sequence database revealed the existence of homologs of $a h l R$ and $a h l I$ genes that encode members of the LuxR-LuxI family of regulatory proteins. By using an E. coli-based bioassay system (Chatterjee et al. 1995), we detected $N$-acyl-homoserine lactone (AHL) in spent cultures of DC3000 and its $\mathrm{GacA}_{\mathrm{DC} 3000}{ }^{-}$mutant. DC3000 produced $1.3 \times 10^{7}$ relative light units (RLU), and its mutant,
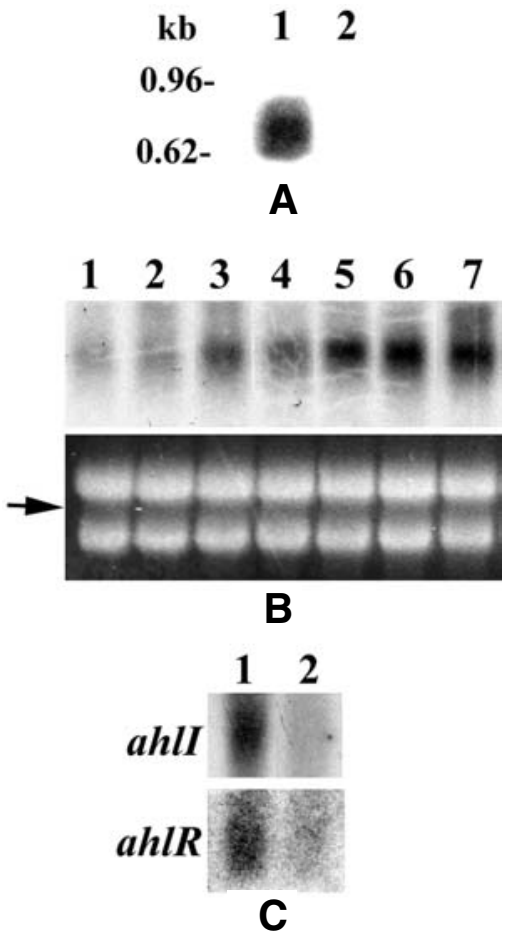

Fig. 1. A, Transcript of $g a c A_{D C 3000}$. Bacteria were grown in King's B (KB) medium at $28^{\circ} \mathrm{C}$ to a Klett value of approximately 100 and were switched into hrp-inducing medium (IM) for an additional 2-h incubation, and cells were harvested for total RNA extraction. Lane 1, DC3000 (wild type) and lane 2, AC811 $\left(\mathrm{GacA}_{\mathrm{DC} 3000^{-}}\right)$. B, Effects of media and growth phase on the transcript levels of $g_{a c} A_{D C 3000}$. Bacteria were grown at $28^{\circ} \mathrm{C}$ in $\mathrm{KB}$ to Klett values of approximately 100 , 200 , and 300 for total RNA extraction. When the culture reached a Klett value of approximately 100 in KB medium, half of the culture was transferred to IM and was incubated for an additional $0.5,1,1.5$, or $2 \mathrm{~h}$, and total RNAs were extracted. Lanes 1 through 3, DC3000 in $\mathrm{KB}$ at Klett values of approximately 100, 200, and 300 and lanes 4 through 7, DC3000 in IM after $0.5,1,1.5$, and $2 \mathrm{~h}$ of incubation, respectively. The arrow shows the levels of total RNA as revealed by ethidium bromide staining of the denaturing agarose gel. C, Effects of $\mathrm{GacA}_{\mathrm{DC} 3000}$ on the transcript levels of $a h l I$ and $a h l R$. Total RNAs were extracted from bacteria grown in KB medium to a Klett value of approximately 100 and were incubated in IM for an additional $2 \mathrm{~h}$. Column 1, DC3000; and column 2, AC811. Each lane contained A, 20 $\mu \mathrm{g}$ and $\mathbf{B}$ and $\mathbf{C}, 15 \mu \mathrm{g}$ of total RNA. 
AC811, produced $1.0 \times 10^{6} \mathrm{RLU}$ when grown in KB medium for $20 \mathrm{~h}$. Northern blot analysis of total RNAs from cultures incubated in IM medium also revealed that the transcript levels of ahlI and ahlR were much lower in AC811 than in DC3000 (Fig. 1C).

Effects of $\mathrm{GacA}_{\mathrm{DC} 3000}$ on growth, motility, and pigment and siderophore production.

To test the effect of GacA ${ }_{\mathrm{DC} 3000}$ on growth, motility, and pigment and siderophore production, the $\mathrm{Gac}_{\mathrm{DC} 3000}{ }^{-}$mutant AC811 and its parent were grown in minimal salts plus succinic acid (disodium salt, $0.5 \% \mathrm{wt} / \mathrm{vol}$ ) medium, KB medium, SWM agar plate (Kinscherf and Willis 1999), and chrome azurolS (CAS) agar plate (Schwyn and Neilands 1987). The growth curves (Fig. 2) of DC3000 and AC811 in minimal salts plus succinic acid and $\mathrm{KB}$ revealed that: i) the mutant reached stationary phase at a slightly lower cell density compared with its parent in both $\mathrm{KB}$ and minimal media and ii) the doubling time (e.g., time required for growth from Klett values of 50 to 100) of DC3000 was approximately $2 \mathrm{~h}$ in both of the media, whereas the mutant has a doubling time of approximately $2 \mathrm{~h}$ in $\mathrm{KB}$ and $2.5 \mathrm{~h}$ in minimal salts plus succinic acid.

DC3000, like many other Pseudomonas species, produces diffusible yellow pigment on $\mathrm{KB}$ agar medium. As shown in Figure 3A, the $\mathrm{GacA}^{-}$mutant $\mathrm{AC} 811$ is much lighter in color than its parent.

To examine the $\mathrm{GacA}_{\mathrm{DC} 3000}$ effect on motility, DC3000 and its $\mathrm{GacA}_{\mathrm{DC} 3000^{-}}$mutant were patched on SWM medium and were incubated for $12 \mathrm{~h}$ at $28^{\circ} \mathrm{C}$. The results shown in Figure $3 \mathrm{~B}$ reveal that the swarming motility of the mutant is much reduced compared with that of DC 3000 .

To test the effect of GacA on the siderophore production, DC3000 and its $\mathrm{GacA}_{\mathrm{DC} 3000}{ }^{-}$mutant $\mathrm{AC} 811$ were grown on CAS agar plate. Contrary to pigment production and swarming motility, Gac $\mathrm{A}_{\mathrm{DC} 3000}$ deficiency does not affect siderophore production (data not shown).
GacA $_{\text {DC3000 }}$ affects the capacity

to elicit the hypersensitive response (HR).

The results in Figure 3C show that DC3000 elicited typical HR in tobacco leaf (Nicotiana tabacum L. cv. Samsun) when infiltrated with $1 \times 10^{7} \mathrm{CFU}$ per ml of bacterial cells (Fig. 3C, site 1), whereas the $\mathrm{Gac}_{\mathrm{DC} 3000}$ mutant failed to elicit the HR symptom at that cell concentration (Fig. 3C, site 2). Both the mutant and parent induced the HR when $1 \times 10^{8} \mathrm{CFU}$ per $\mathrm{ml}$ of bacterial cells were infiltrated (data not shown).

\section{Effects of Gac $\mathrm{A}_{\mathrm{DC} 3000}$ on pathogenicity.}

To compare the effects of $\mathrm{Gac}_{\mathrm{DC} 3000}$ on pathogenicity, we tested the responses of DC3000 and its $\mathrm{GaCA}_{\mathrm{DC} 3000}{ }^{-}$mutant in Arabidopsis and tomato plants. Arabidopsis leaves were infiltrated with $1 \times 10^{6} \mathrm{CFU}$ per ml of bacterial cells of DC3000 or its $\mathrm{GacA}^{-}$mutant, AC811. Tomato leaves were dip-inoculated in $2 \times 10^{8} \mathrm{CFU}$ per $\mathrm{ml}$ of bacterial cell suspensions. Figure $3 \mathrm{D}$ shows that DC3000 produced disease symptoms in Arabidopsis leaves. In contrast, the $\mathrm{Gac}_{\mathrm{DC} 3000}{ }^{-}$mutant failed to produce any disease. The results shown in Figure $3 \mathrm{E}$ reveal that the severity of symptom production in tomato leaves by the $\mathrm{GacA}_{\mathrm{DC} 3000^{-}}$mutant (right) was much reduced as compared with DC3000 (left). This observation correlated with bacterial cell population in tomato leaves (Fig. $3 \mathrm{~F}$ ) in that the population of the mutant cells was lower than that of the parent for two to five days postinoculation.

\section{GacA $_{\text {DC3000 }}$ controls regulatory genes.}

Alternate sigma factors. HrpL, an alternate sigma factor, plays a central role in the production of the type III secretion system and the proteins (= effectors) secreted by this pathway (Chatterjee et al. 2002; Collmer et al. 2000, 2002; Fouts et al. 2002; Frederick et al. 2001; Mor et al. 2001; Petnicki-Ocwieja et al. 2002; Wei and Beer 1995; Wei et al. 2000; Xiao et al. 1994). The results shown in Figure 4A reveal that the transcript levels of $h r p L$ and $r p o N$ (sigma54), an alternate sigma factor required for expression of $h r p L$ (Chatterjee et al. 2002;

Table 1. Bacterial strains and plasmids used in this research

\begin{tabular}{|c|c|c|}
\hline Strain / plasmid & Relevant characteristics & Source/Reference \\
\hline \multicolumn{3}{|l|}{ Strains } \\
\hline \multicolumn{3}{|c|}{ Erwinia carotovora subsp. carotovora } \\
\hline Ecc71 & Wild type & Zink et al. 1984 \\
\hline AC5056 & $\mathrm{Gm}^{\mathrm{r}}, \mathrm{GacA}^{-}$derivative of Ecc71 & Cui et al. 2001 \\
\hline AC5088 & $\mathrm{Cm}^{\mathrm{r}}, \mathrm{RsmB}$ derivative of Ecc71 & Chatterjee et al. 2002 \\
\hline \multicolumn{3}{|c|}{ Pseudomonas syringae pv. tomato } \\
\hline DC3000 & Wild type & A. Collmer \\
\hline AC811 & $\mathrm{Km}^{\mathrm{r}}, \mathrm{GacA}_{\mathrm{DC} 3000}^{-}$derivative of $\mathrm{DC} 3000$ & This work \\
\hline \multicolumn{3}{|c|}{ P. syringae pv. syringae } \\
\hline B728a & Wild type & K. Willis \\
\hline BGACX & $\mathrm{Km}^{\mathrm{r}}, \mathrm{GacA}^{-}$derivative of B728a & Rich et al. 1994 \\
\hline \multicolumn{3}{|l|}{ P. fluorescens } \\
\hline $7-14$ & Wild type & Chatterjee et al. 1996 \\
\hline \multicolumn{3}{|l|}{ Plasmids } \\
\hline pCРP47 & $\mathrm{Tc}^{\mathrm{r}}$ & \\
\hline pKnockout $\Omega$ & $\mathrm{Sp}^{\mathrm{r}}$, vector & Windgassen et al. 2000 \\
\hline pMMB66EH & $\mathrm{Ap}^{\mathrm{r}}$, vector & Fürste et al. 1986 \\
\hline pMMB66ЕH $\Omega$ & $\mathrm{Sp}^{\mathrm{r}}, \mathrm{Sp}^{\mathrm{r}}$ cassette inserted at $P v u \mathrm{I}$ site of $\mathrm{pMMB} 66 \mathrm{EH}$ & This work \\
\hline pUT mini-Tn5-Km & $\mathrm{Km}^{\mathrm{r}}$, a lambda-pir vector containing mini- $\mathrm{Tn} 5-\mathrm{Km}$ transposon & de Lorenzo et al. 1990 \\
\hline pAKC1111 & $\mathrm{Tc}^{\mathrm{r}}, \mathrm{GacA}_{\mathrm{DC} 3000}{ }^{+}$from DC3000 genomic library in pCPP47 & This work \\
\hline pAKC1112 & $\mathrm{Km}^{\mathrm{r}}, \mathrm{Tc}^{\mathrm{r}}, \mathrm{GacA}_{\mathrm{DC} 3000}^{-}, \mathrm{pAKC} 1111$ mutagenized by mini-Tn $5-\mathrm{Km}$ & This work \\
\hline pAKC1114 & $\mathrm{Tc}^{\mathrm{r}}, g a c A_{D C 3000}$ with $372 \mathrm{bp}$ upstream in pRK415 & This work \\
\hline pLN4 & $\mathrm{Sp}^{\mathrm{r}}, 700$ bp of hopPtoD1 in pKnockout $\Omega$ & J. Alfano \\
\hline pLN5 & $\mathrm{Sp}^{\mathrm{r}}, 570 \mathrm{bp}$ of hopPtoD2 in pKnockout $\Omega$ & J. Alfano \\
\hline pLN6 & $\mathrm{Sp}^{\mathrm{r}}, 790 \mathrm{bp}$ of hopPtoC in pKnockout $\Omega$ & J. Alfano \\
\hline pLN7 & $\mathrm{Sp}^{\mathrm{r}}, 700$ bp of hopPtoF in pKnockout $\Omega$ & J. Alfano \\
\hline pLN8 & $\mathrm{Sp}^{\mathrm{r}}, 700 \mathrm{bp}$ of hopPtoJ in $\mathrm{pKnockout} \Omega$ & J. Alfano \\
\hline pLN9 & $\mathrm{Sp}^{\mathrm{r}}, 700 \mathrm{bp}$ of hopPtoK in pKnockout $\Omega$ & J. Alfano \\
\hline pHL2B & $\mathrm{Ap}^{\mathrm{r}}, c f l$ in pBluescript $\mathrm{SK}+$ & C. Bender \\
\hline
\end{tabular}


Hendrickson et al. 2000), are much reduced in the $\mathrm{Gac}_{\mathrm{DC} 3000}$ mutant compared with those in its parent.

Contrary to the results of DC3000, the elicitation of the HR is not affected by GacA in $P$. syringae pv. syringae $\mathrm{B} 728 \mathrm{a}$ (Willis et al. 1990). Northern blot analysis results (Fig. 4B) revealed that the transcript levels of $h r p L$ are very similar in B728a and its $\mathrm{GacA}^{-}$mutant BGACX.

Stationary-phase sigma factor $\sigma^{\mathrm{s}}(\operatorname{rpoS})$ is positively regulated by GacA in $P$. fluorescens and $E$. coli (Mukhopadhyay et al. 2000; Whistler et al. 1998). Our data (Fig. 4A) show a similar effect of $G a c A_{\mathrm{DC} 3000}$ on the expression of $r p o S$ in DC3000. However, the expression of algT (encoding sigma E) is not affected by $\mathrm{GacA}_{\mathrm{DC} 3000}$ (Fig. 4A).

hrpRS, regulatory genes controlling hrpL expression. In $P$. syringae pv. tomato as well as $P$. syringae pv. syringae, $h r p L$ is controlled by the NtrC-like regulators HrpRS that, in conjunction with sigma-54, activate the $h r p L$ promoter (Hendrickson et al. 2000). In light of the effects of GacA on hrpL RNA levels (discussed above), the effect of GacA deficiency on the expression of hrpRS genes was tested. The results of Northern blot analysis (Fig. 4C) showed that both $h r p R$-specific and hrpSspecific probes hybridized to the same 2.1- (Fig. 4C, band a) and 1.1-kb (Fig. 4C, band b) RNA species of DC3000. The 1.1-kb RNA species, like the 2.1-kb RNA, carries sequences for both the genes and is presumed to represent a relatively stable degradation product. These data confirm the observations of Hutcheson and associates (2001) that $h r p R$ and $h r p S$ compose an operon. With the $h r p R$-specific probe, we noted hybridization with an approximately 0.5 -kb RNA species (Fig. 4C, band c) that most likely is the processed product of the hrpRS transcripts. We do not yet know if $h r p R$ and $h r p S$ are differentially expressed or if RNA processing plays a role in such expression. This uncertainty notwithstanding, our data clearly establish that the $\mathrm{GacA}^{-}$mutant, compared with the $\mathrm{GacA}^{+}$parent, makes much-reduced levels of the 2.1-kb hrpRS transcript and the RNA species derived from it.

SalA, a DNA-binding regulatory protein. In $P$. syringae pv. syringae, the production of syringomycin as well as virulence are controlled by SalA (Kitten et al. 1998; Lu et al. 2002). Our results revealed that, in DC3000 and AC811, the transcript levels of salA were higher in IM medium than in $\mathrm{KB}$ medium (Fig. 4D, lanes 1 and 3) and that compared with DC3000, the transcript levels of salA in $\mathrm{GacA}_{\mathrm{DC} 3000}{ }^{-}$mutant were reduced in both $\mathrm{KB}$ and IM media (Fig. 4D, lanes 2 and 4 compared with lanes 1 and 3 , respectively).

$\operatorname{corR}$, corS, and coronatine biosynthetic genes. Since coronatine is an important virulence factor (Bender et al. 1999;

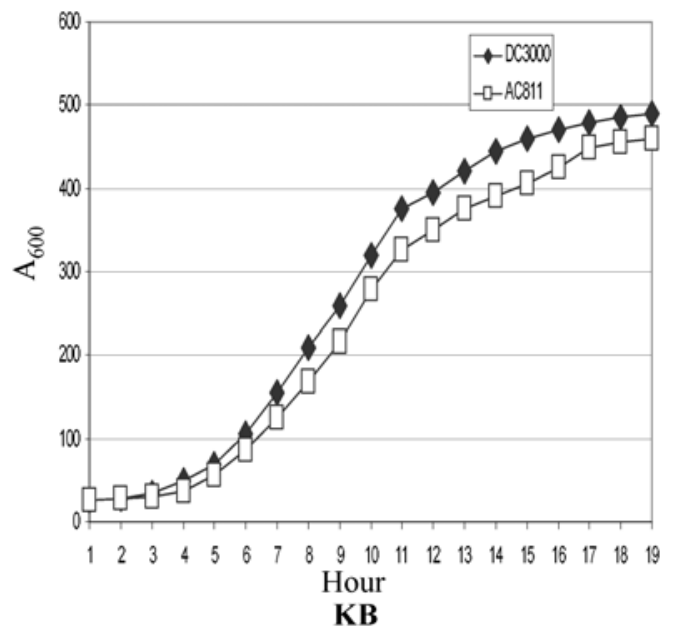

Ullrich et al. 1995) and GacA affects virulence of DC3000 (Fig. 3D and E), the effect of GacA on coronatine regulatory and biosynthetic gene expression was examined. Extensive studies by Bender and associates (Bender et al. 1999; Peñaloza-vázquez and Bender 1998; Rangaswamy and Bender 2000; Wang et al. 1999) and that of Smirnova et al. (2002) have established that CorS and CorR, members of a modified two-component system, control the biosynthetic genes. A Blast search of the DC3000 whole genome sequence disclosed the presence of $\operatorname{cor} S$ and $\operatorname{cor} R$ sequences. CorS is predicted to function as a sensor kinase, whereas CorR is believed to function as a response regulator. To assess the roles of GacA on these putative cor regulatory genes, we conducted Northern blot assays (Fig. 4E). It is evident that $\operatorname{corR}$ and $\operatorname{corS}$ RNA levels are reduced more in the $\mathrm{GacA}^{-}$mutant than in DC3000. Consistent with this observation was the effect of GacA deficiency on several biosynthetic genes (Fig. 5). The $\mathrm{GacA}^{--}$mutant produced barely detectable levels of transcripts of $c f l$, a gene for coronafacate ligase, as well as of $c f a 8$ and $c f a 9$, genes involved in coronatine biosynthesis. These data clearly contrast with high levels of transcripts of these cor genes in DC3000.

$r s m B$ and $r s m Z$ RNA species. $r s m B$, a nontranslatable RNA molecule, belongs to the RsmA-rsmB posttranscriptional regulatory system. It binds RsmA, an RNA binding protein promoting mRNA decay, and neutralizes the action of RsmA. Our previous work in Erwinia carotovora revealed that GacA positively regulates $r s m B$.

In $P$. fluorescens, rsmZ (prrb), which is structurally similar to $r \operatorname{smB}$, was found to be positively controlled by GacA (Aarons et al. 2000; Heeb et al. 2002). Overexpression of rsmZ increased the production of $\mathrm{Phl}$ (2, 4-diacetylphloroglucinol) and hydrogen cyanide (Aarons et al. 2000; Heeb et al. 2002).

To assess the regulatory effects of GacA on $r s m B$ and $r s m Z$ in $\mathrm{DC} 3000$, we cloned a $r \operatorname{sim} B_{D C 3000}$ and a $r s m Z_{D C 3000}$ locus from a DC3000 genomic library. The Northern blot data (Fig. 4F) show that DC3000 produced high levels of $r \operatorname{smB}$ and $r \operatorname{sm} Z$ transcripts, whereas the mutant produced barely detectable levels of $r s m B$ and reduced levels of $r s m Z$ transcripts.

\section{Effects of GacA $_{\mathrm{DC} 3000}$ on the transcript levels of $h r p L$-dependent and $h r p L$-independent genes.}

Our data demonstrated that the transcript levels of $h r p L$ are positively regulated by $\mathrm{GacA}_{\mathrm{DC} 3000}$ (Fig. 4A), most likely due to its effects on hrpRS and rpoN. Recent studies have established a fundamental role of HrpL in the expression of many $h r p, h r c$, and hop genes and virulence effector genes known or predicted to posses the HrpL promoter (Boch et al. 2002; Chatterjee et al.

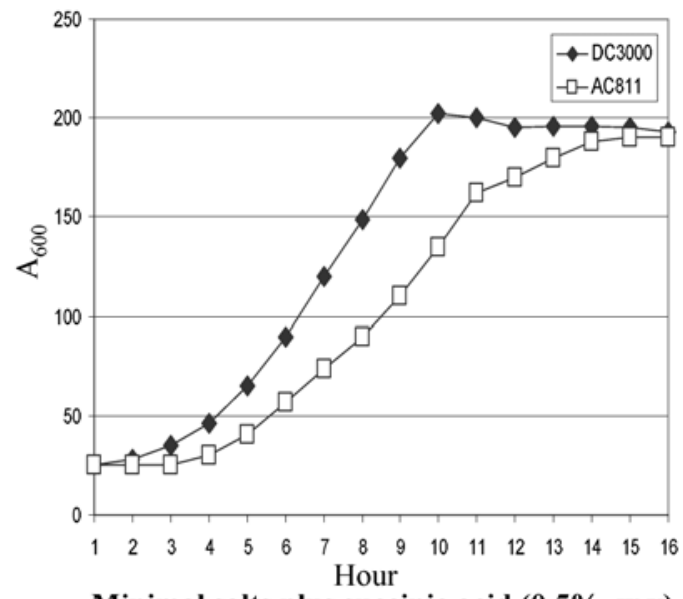

Minimal salts plus succinic acid $(0.5 \%$, w.v $)$

Fig. 2. Growth curve of $\mathrm{DC} 3000$ and its $\mathrm{Gac}_{\mathrm{DC} 3000^{-}}$mutant $\mathrm{AC} 811$ in King's B medium and minimal salts plus succinic acid $(0.5 \%$ wt/vol $) \mathrm{media}$. 
2002; Collmer et al. 2000, 2002; Fouts et al. 2002; Frederick et al. 2001; Guttman et al. 2002; Mor et al. 2001; PetnickiOcwieja et al. 2002; Wei and Beer 1995; Wei et al. 2000; Xiao et al. 1994). To test the effect of GacA deficiency, we determined the transcript levels of HrpL-dependent genes in DC3000 and its $\mathrm{GacA}_{\mathrm{DC} 3000}{ }^{-}$mutant (Fig. 5A). It is apparent that RNA levels of the following genes were much lower in the mutant: i) $h r p Z$, encoding harpin and $h r p C$, which specifies a component of the type III secretion system; ii) eight virulence effector genes (hopPtoD1, hopPtoD2, hopPtoC, avrPpiB,
hopPtoF, hopPtoJ, hopPtoK, and avrPtoB); iii) hopPtoM and hopPtoN, which are located within the pathogenicity island; and iv) $h o p P m a H_{\text {Pto }}$ encoding a pectin lyase. By contrast, in $P$. syringae $\mathrm{pv}$. syringae $\mathrm{B} 728 \mathrm{a}$, the transcript levels of $h r p Z$ are not affected by GacA deficiency (Fig 4B).

Recent observations have revealed that several genes possessing HrpL-independent promoters are required for pathogenicity and virulence of DC3000 (Boch et al. 2002). This finding, taken along with a severe negative effect of GacA deficiency on pathogenicity, prompted us to test the effects of
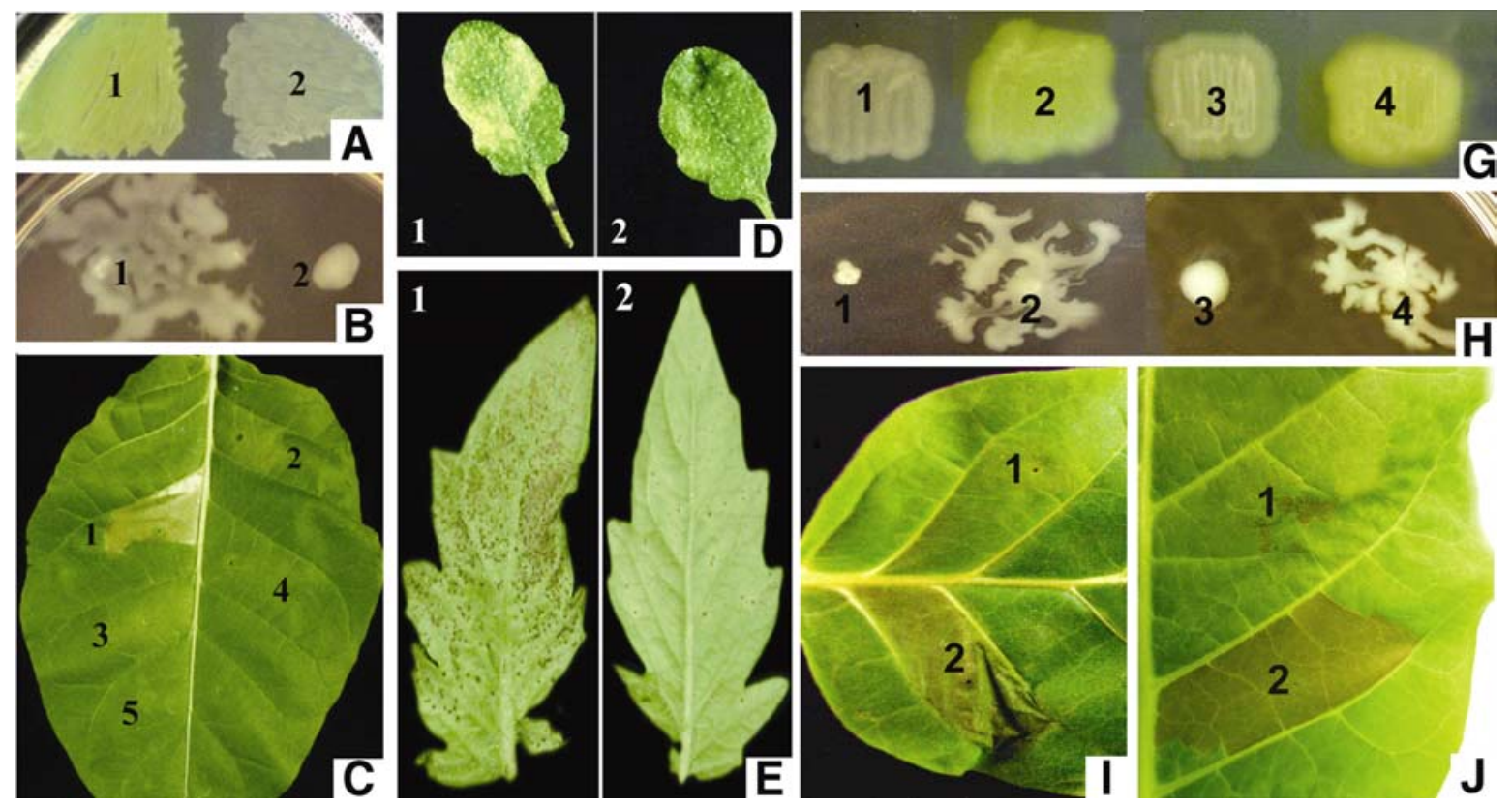

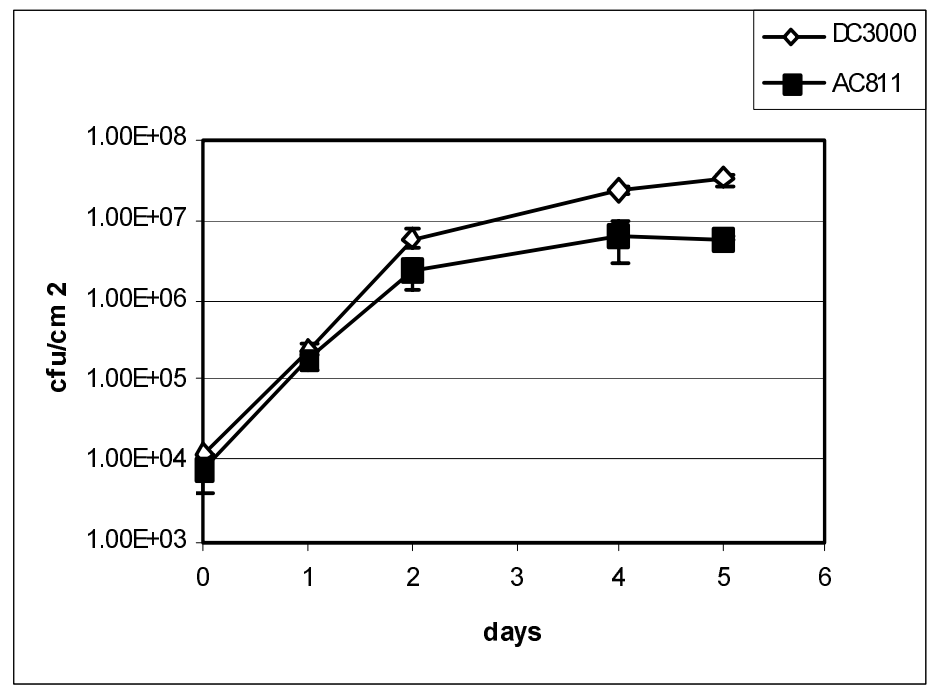

$\mathbf{F}$

Fig. 3. A, Pigment production by DC3000 (1) and its $\mathrm{Gac}_{\mathrm{DC} 3000}{ }^{-}$mutant $\mathrm{AC} 811$ (2). Bacterial cells were inoculated on King's $\mathrm{B}$ (KB) agar and incubated at $28^{\circ} \mathrm{C}$ for $24 \mathrm{~h}$. B, Swarming motility of DC3000 (1) and AC811 (2). Bacterial cells were inoculated on SWM agar (0.4\% agar) and were incubated at $28^{\circ} \mathrm{C}$ for $24 \mathrm{~h}$. C, Effect of the disruption of $\mathrm{GacA}_{\mathrm{DC} 3000}$ on the elicitation of the hypersensitive response (HR) by DC3000 in tobacco leaf (Nicotiana tabacum L. cv. Samsun). DC3000 and AC811 were grown on KB agar overnight at $28^{\circ} \mathrm{C}$, and cells were suspended in water. Leaf panels were infiltrated with bacterial cells. The picture was taken $20 \mathrm{~h}$ after inoculation. Site 1 , DC3000 $\left(1 \times 10^{7} \mathrm{CFU} / \mathrm{ml}\right)$; site 2 , AC811 $\left(1 \times 10^{7}\right)$; site 3 , DC3000 $\left(5 \times 10^{6}\right)$; site 4, AC811 $\left(5 \times 10^{6}\right)$; and site 5, water. D, Disease symptoms caused by DC3000 (1) and AC811 (2) in Arabidopsis leaves. Bacterial cells were grown on $\mathrm{KB}$ agar overnight at $28^{\circ} \mathrm{C}$, and cells were suspended in water. Leaves were infiltrated with bacterial cells $\left(1 \times 10^{6} \mathrm{CFU} / \mathrm{ml}\right)$. The pictures were taken four days after inoculation. E, Disease symptoms caused by DC3000 (1) and AC811 (2) in tomato leaves. Bacterial cells were grown on KB agar overnight at $28^{\circ} \mathrm{C}$, and cells were suspended in water containing Silwet L-77 $(0.02 \% \mathrm{vol} / \mathrm{vol})$ to $2 \times 10^{8} \mathrm{CFU} / \mathrm{ml}$. Leaves were dip-inoculated in bacterial suspensions. The pictures were taken five days after inoculation. F, Population of DC3000 and AC811 in tomato leaves after inoculation. G, Pigment production by $\mathrm{GacA}_{\mathrm{DC} 3000}{ }^{-}$mutant AC811 carrying pCPP47 (vector)(1), pAKC1111 $\left(\mathrm{GaCA}_{\mathrm{DC} 3000}{ }^{+}\right)(2), \mathrm{pRK} 415$ (vector)(3) and pAKC1114 $\left(\mathrm{GacA}_{\mathrm{DC} 3000}{ }^{+}\right)(4)$. $\mathrm{H}_{2}, \mathrm{Swarm}^{-}$ ing motility of AC811 carrying pCPP47 (1), pAKC1111 (2), pRK415 (3) and pAKC1114 (4). I, The HR caused by AC811 carrying pCPP47 (site $1,1 \times$ $10^{7}$ ) and pAKC1111 (site $2,1 \times 10^{7}$ ). J, The HR caused by AC811 carrying pRK415 (site $1,1 \times 10^{7}$ ) and pAKC1114 (site $2,1 \times 10^{7}$ ). The pictures were taken $20 \mathrm{~h}$ after inoculation. 
$\mathrm{Gac}_{\mathrm{DC} 3000}$ on several $h r p L$-independent genes. RNA levels of fliO, a gene encoding flagellar protein, and cel orfl, a gene encoding lytic murein transglycosylase, were also lower in the mutant compared with that of DC3000. Likewise, $\operatorname{tnp} A$, the gene encoding transposase, and $f a d D$, the gene for long-chain fatty acid CoA ligase, presumed not to affect pathogenicity, were also negatively affected by GacA deficiency. By contrast, the transcript levels of $c a t F$, a gene encoding catalase, and $\operatorname{alg} D$, a gene encoding GDP mannose dehydrogenase are not affected by $\mathrm{GacA}_{\mathrm{DC} 3000}$ (Fig. 5B).

\section{Restoration of $\mathrm{GacA}_{\mathrm{DC} 3000}$ controlled traits in $\mathrm{AC811}$ by gacA $_{\mathrm{DC} 3000}{ }^{+}$plasmid.}

To rigorously test that the phenotypic changes in AC811 resulted from inactivation of $g a c A_{D C 3000}$, we constructed pAKC1114, which contains the $g a c A_{D C 3000}$ DNA as well as 372 bp upstream in pRK415. This plasmid or pAKC1111 containing DC3000 gacA and flanking DNA in pCPP47 were transferred into AC811 and tested for various phenotypes. The results revealed that pigment production (Fig. 3G), motility (Fig. 3H), and capacity to elicit the HR (Fig. 3I and J) were restored to the wild-type level by pAKC1111 or pAKC1114 in AC811. The transcript levels of salA, rsmB, rsmZ, hrpL, hrpZ, and hopPtoC were also higher in AC811 carrying pAKC1111 or pAKC1114 than in AC811 carrying the cloning vectors (Fig. $4 G)$. Since pAKC1114 carries only the $g_{a c} A_{D C 3000}$ DNA, we conclude that the phenotypes changed in AC811 due to GacA deficiency.

\section{DISCUSSION}

In this report, we have presented significant new findings on the effects of GacA, a response regulator of a two-component system of $P$. syringae pv. tomato DC3000. Our data reveal that GacA plays a central regulatory role by controlling the production of various alternate sigma factors, quorum sensing signal and regulatory RNA, and protein species. The regulatory scheme depicted in Figure 6 places GacA at the top in the regulatory hierarchy, based upon the effect of GacA on regulators known or predicted to control expression of various bacterial traits. The observations that are especially relevant to the biology and ecology of this bacterium include effects on movement, production of secondary metabolites, including the putative quorum sensing signal, overall performance as a pathogen, and capacity to produce virulence effectors and to elicit host defense responses. We discuss below the findings in light of

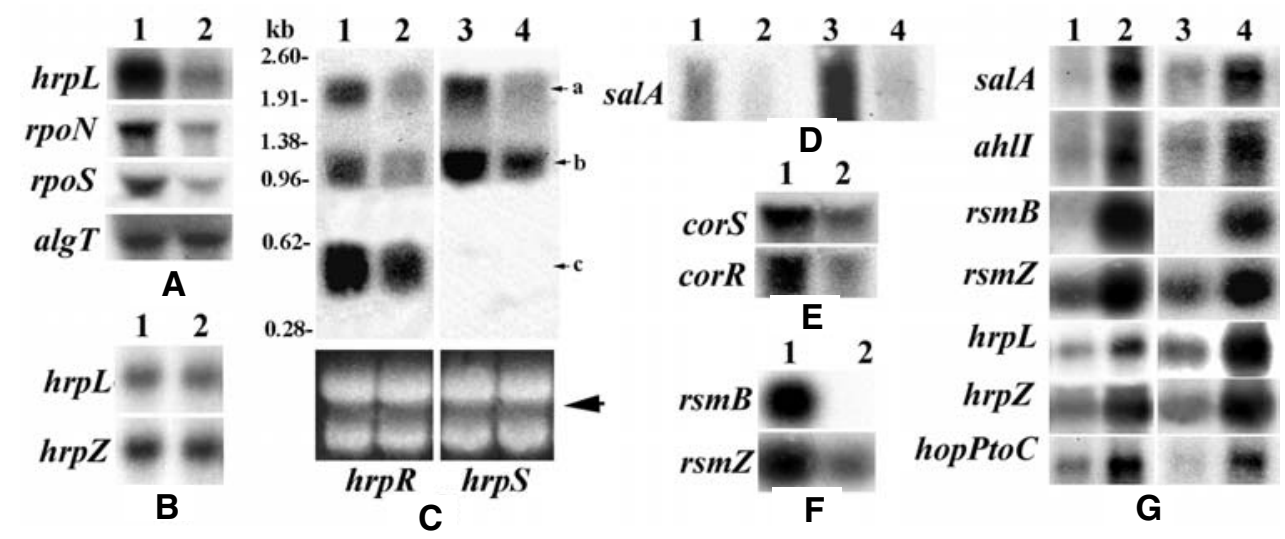

Fig. 4. A, Transcript levels of $h r p L, r p o N, r p o S$, and algT of DC3000 and AC811. Column 1, DC3000 and column 2, AC811. B, Transcript levels of $h r p L$ and hrpZ of P. syringae pv. syringae B728a (column 1) and its GacA mutant BGACX (column 2). C, Transcript levels of hrpR and hrpS of DC3000 and AC811. Column 1 and 3, DC3000 and column 2 and 4, AC811. The arrow head shows the level of total RNA as revealed by ethidium bromide staining of the denaturing agarose gel. D, Transcript levels of salA of DC3000 and AC811 in King's B (KB) medium (lanes 1 and 2) and $h r p$-inducing medium (IM) (lanes 3 and 4). Lanes 1 and 3, DC3000 and lanes 2 and 4, AC811. E, Transcript levels of corS and corR of DC3000 (column 1) and AC811 (column 2). F, Effects of $\mathrm{GacA}_{\mathrm{DC} 3000}$ on the transcript levels of $r s m B$ and $r s m Z$. Column 1, DC3000 and column 2, AC811. G, Transcript levels of salA, ahlI, rsmB, rsmZ, hrpL, hrpZ, and hopPtoC in AC811 carrying the vector pCPP47 (column 1), the GacA $\mathrm{DC}_{3000}{ }^{+}$plasmid pAKC1111 (column 2), the vector pRK415 (column 3 ) and the $\mathrm{GacA}_{\mathrm{DC} 3000}{ }^{+}$plasmid pAKC1114 (column 4). For rpoS, and salA (lanes 1 and 2 of D), total RNAs were obtained from bacteria grown in KB medium to a Klett value of approximately 200 and for $h r p L$ of DC3000 and B728a, rpoN, algT, hrpZ, hrpR, hrpS, salA (lanes 3 and 4 of D and lanes 1 and 2 in G), corS, $\operatorname{cor} R, r s m B$, and $r s m Z$, total RNAs were extracted from bacteria grown in KB to a Klett value of approximately 100 and incubated in IM for $2 \mathrm{~h}$. Each lane contained $15 \mu \mathrm{g}$ of total RNA.

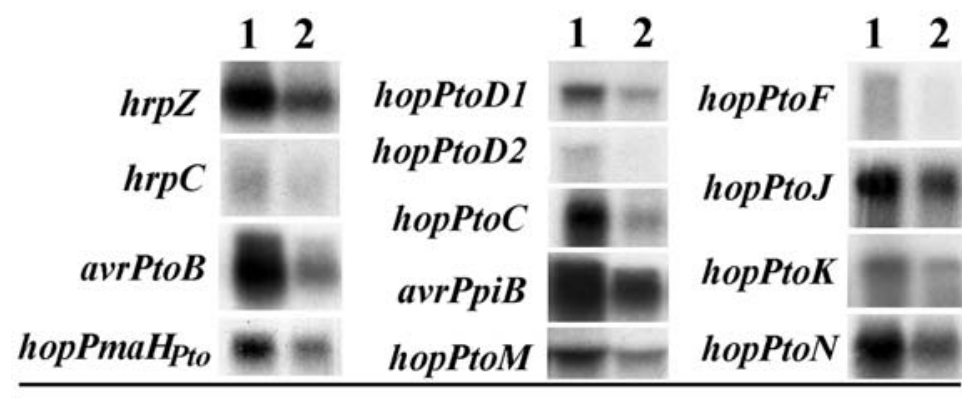

A

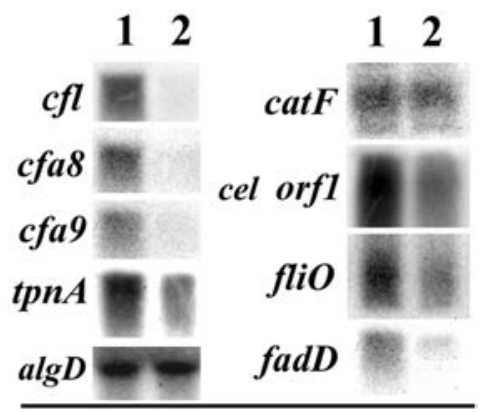

B

Fig. 5. Effects of $\mathrm{GacA}_{\mathrm{DC} 3000}$ on the transcript levels of A, HrpL-dependent genes and B, HrpL-independent genes. Total RNAs were obtained from bacteria grown in King's B medium to a Klett value of approximately 100 and incubated in hrp-inducing medium for an additional 2 h. Each lane contained 15 $\mu \mathrm{g}$ of total RNA. Column 1, DC3000 and column 2, AC811. 
our observations and those reported for other related bacteria. It should be noted that GacA does not affect the expression of several genes including $\operatorname{alg} T$ (Fig. 4A), $\operatorname{algD}$, and $c a t F$ (Fig. 5B), as well as $r s m A$ (A. Chatterjee, unpublished data). Therefore, the results seem to appear specific to genes in the GacA regulon and not to a general physiological effect on gene expression.

$\mathrm{Gac}_{\mathrm{DC} 3000}$ shares high homology with GacA proteins of various Pseudomonas species and, like the other GacA species, it contains a putative response regulatory domain within the $\mathrm{N}$ terminal, a putative HTH motif of the LuxR family, likely involved in DNA binding in the $\mathrm{C}$-terminal. The C-terminal HTH motif is predicted to determine DNA recognition specificity of GacA. Mutational analyses of $g a c A_{D C 3000}$, especially mutations in these domains, are needed to define their functions in regulation of gene expression. With regard to the primary target of $\mathrm{Gac}_{\mathrm{DC} 3000}$, our findings, albeit somewhat preliminary, make a case for $r s m B$ and $r s m Z$ RNA. First, the expression of $r s m B$ and $r s m Z$ is severely reduced in the absence of GacA. Second, multiple copies of $r \mathrm{smB}$ reverse the effects of GacA deficiency; this reversal is more pronounced when a non-GacA-responsive promoter replaces the native GacA-responsive $r s m B$ promoter (A. Chatterjee, unpublished data). We should note that $r s m B_{D C 3000}$ acts as a positive regulator in Erwinia carotovora $\mathrm{RsmB}^{-}$mutant AC5088, in P. syringae pathovars, including DC3000, and in P. fluorescens strains (A. Chatterjee, unpublished data).

While GacA affects a large array of traits (Heeb and Haas 2001), the specific traits affected in different bacterial species or subspecies may differ. In P. aeruginosa PA14 (Parkins et al. 2001), GacA was found to affect biofilm formation but not flagellar-mediated attachment, solid surface translocation by pili, autoinducer production, or alginate biosynthesis. This contrasts with the effects of GacA on swarming motility and AHL production by DC3000 as reported here. GacA and GacS were found to control quorum sensing signal in $P$. aureofaciens (Chancey et al. 1999) and P. syringae pv. syringae (Dumenyo et al. 1998; Kinscherf and Willis 1999; Kitten et al. 1998) as well. Alginate production is controlled by GacS and GacA in Azotobacter vinelandii (Castañeda et al. 2001) and P. syringae pv. syringae B728a (Willis et al. 2001). However, in DC3000, no effect of $\mathrm{GacA}$ on $\operatorname{alg} T(\operatorname{alg} U)$ and $\operatorname{alg} D$ transcript levels were seen (Figs. 4A and 5B). In P. syringae pv. syringae B728a (Willis et al. 1990), GacA and GacS affect pathogenicity but not HR. This finding contrasts with the effects of GacA on both HR and pathogenicity of DC3000 (discussed below). Our observations suggest that such differences reflect the composition of the GacS and GacA regulatory cascade, i.e., the nature of the downstream regulatory genes that are affected by GacS and GacA.

In the context of plant interaction of DC3000, the regulation of $h r p L$, salA, corR, and corS by GacA is especially critical. The pioneering work of N. Panopoulos (Rahme et al. 1991) and subsequent elegant studies of S. W. Hutcheson (Bretz et al. 2002; Hutcheson et al. 2001) established the regulatory cascade involved in the expression of $h r p L$. $h r p L$ transcription is activated by HrpR and HrpS, regulators belonging to the NtrC family of enhancer-binding proteins, in conjunction with $\sigma^{54}$. Here, we have documented that GacA controls the expression of $h r p R S$ and $r p o N$, and these findings strongly suggest that the regulatory effect of GacA on $h r p L$ is a consequence of these regulations. In addition to confirming the operon organization of hrpRS in DC3000 (Hutcheson et al. 2001), our data raise the possibility of processing of the transcripts yielding predominantly RNA carrying $h r p R$ sequences. We should note that RNA processing as a means of differential gene expression has been reported for various bacterial operons.

Studies with several Erwinia and Pseudomonas species, including DC3000, have disclosed that HrpL plays a critical role in bacteria-plant interactions. It positively controls the expres-

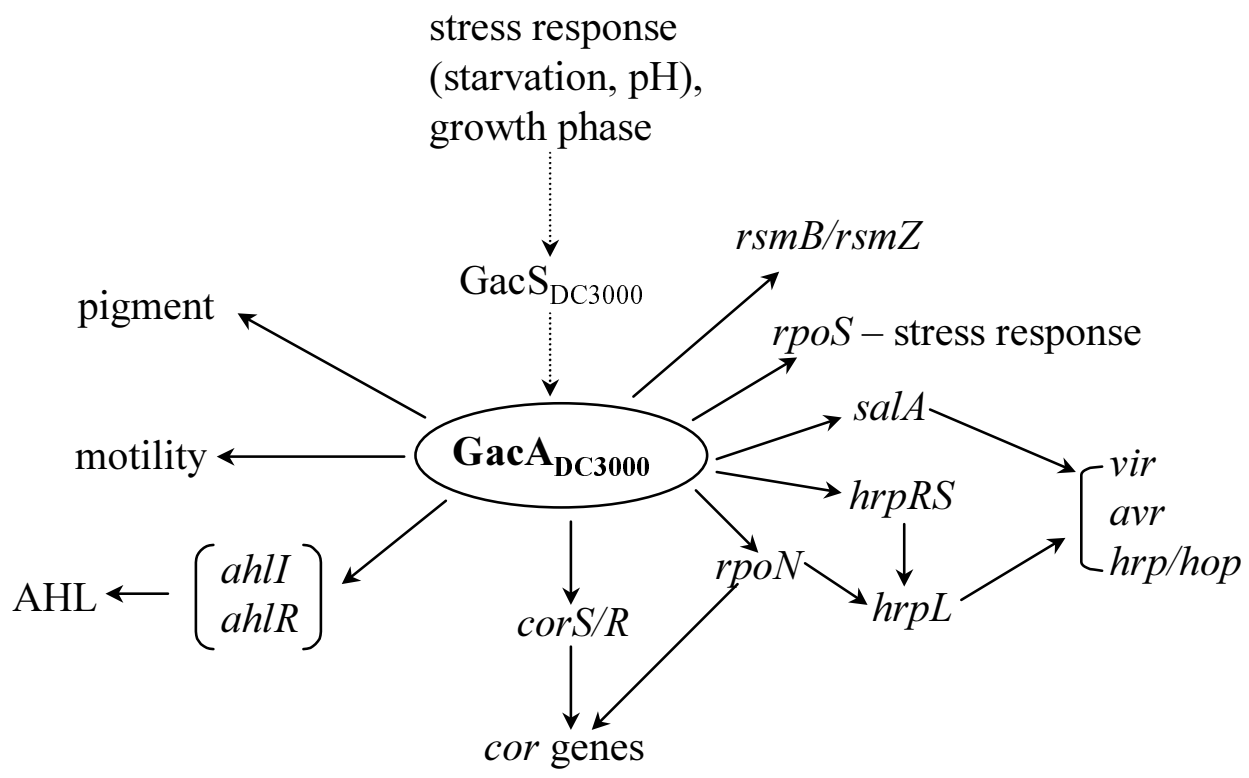

Fig. 6. Schematic depiction of the GacS/A regulon of Pseudomonas syringae pv. tomato DC3000. GacS, the putative sensor kinase, is presumed to respond to cues generated during the postexponential bacterial growth phase and under various physiological and stress conditions. It is likely that, under these conditions, GacS autophosphorylates and then activates GacA. The activated GacA positively regulates the production of several alternate sigma factors, DNA binding proteins, and regulatory RNA species. These observations establish a central regulatory role of GacS and GacA, and place these higher in the regulatory hierarchy. The effects of GacA on various regulators are known or predicted to cause profound changes in bacterial behavior, including movement, pathogenicity, elicitation of defense responses, stress responses, and the production of toxins, pigments, and the putative quorum sensing signal. Several major components, RpoN, HrpL, SalA, and CorS and CorR, known to affect genes for plant interaction, i.e., vir, avr, hrp/hop, as well as cor and $c f a$, are all regulated by the GacS and GacA system. RpoN in conjunction with HrpRS activates hrpL expression, and the genes targeted by HrpL have been identified (Chatterjee et al. 2002; Hendrickson et al. 2000). RpoN is also known to control COR synthesis (Smirnova et al. 2002). By contrast, those controlled by SalA in DC3000 are not yet known. 
sion of $h r p, d s p$, and $a v r$ genes as well as other genes involved in bacterial virulence (Boch et al. 2002; Chatterjee et al. 2002; Collmer et al. 2000; Fouts et al. 2002; Frederick et al. 2001; Guttman et al. 2002; Mor et al. 2001; Wei and Beer 1995; Wei et al. 2000; Xiao et al. 1994). The effects of the GacA-deficient mutant on the elicitation of the HR and its reduced virulence in tomato and Arabidopsis are consistent with the effects on hrpL expression. DC3000 is clearly different from $P$. syringae pv. syringae $\mathrm{B} 728 \mathrm{a}$ in this regard. We should recall that Willis and associates (1990) noted that deficiency of GacS and GacA in B728a apparently had no effect on the elicitation of HR in tobacco leaves but caused the loss of the ability to induce brown spot disease in bean. Our results from Northern blot analysis of the $\mathrm{GacA}^{-}$mutant of B728a (BGACX) and its parent (Fig. 3B) now show that GacA deficiency does not affect the expression of $h r p L$ and $h r p Z$, the latter encodes an effector and is known to be controlled by HrpL. This raises the question why the GacA-deficient mutant of B728a is avirulent but shows the HR. We tentatively attribute this to the effects of GacA-controlled SalA production on hrp, vir, and avr genes of P. syringae pv. syringae B728a (discussed below).

Willis and associates have shown that GacA positively regulates the production of SalA, a putative DNA-binding protein that controls toxin production and pathogenicity in $P$. syringae pv. syringae B728a (Kitten et al. 1998). They have also documented that the effect of SalA on pathogenicity is not due to its effect on toxin production ( $\mathrm{Lu}$ et al. 2002). Thus, it is reasonable to assume that SalA function is dedicated toward the expression of genes for plant interaction in addition to toxinogenesis. We have shown that salA is expressed in DC3000, that the levels of salA $_{D C 3000}$ transcripts are higher in IM than in $\mathrm{KB}$ medium, and that GacA deficiency results in a severe reduction in $s a l A_{D C 3000}$ transcript levels. Extrapolating from the observations of Kitten and associates (1998) with $P$. syringae pv. syringae, we suggest that $\mathrm{SalA}_{\mathrm{DC} 3000}$ controls genes for pathogenicity in DC3000 as well and the GacA effect on virulence is due to the cumulative regulatory effects of $\mathrm{SalA}_{\mathrm{DC} 3000}, \mathrm{HrpL}_{\mathrm{DC} 3000}, \mathrm{CorR}_{\mathrm{DC} 3000}$, and CorS $_{\mathrm{DC} 3000}$ (the effects on CorR and CorSare discussed below). In this regard, B728a and DC3000 behave differently. In B728a, salA but not $h r p L$ expression is affected by GacA, contrasting with effects on both $h r p L$ and salA in DC3000. A systematic search of B728a and DC3000 genes affected by HrpL deficiency and SalA deficiency would be most instructive.

Our data also establish for the first time that $\operatorname{salA}_{D C 3000}$ expression is better stimulated in IM than in KB (Fig. 4D). While we do not have a clear understanding of the significance of this regulation, it is tempting to suggest that DC3000 produces effector proteins under physiologically challenging conditions and, to ensure this response, the bacterium utilizes regulators, i.e., HrpL and SalA, that are themselves stress-activated.

As opposed to SalA, much is now known about the functions of CorR and CorS in the context of coronatine biosynthesis (Bender et al. 1999; Peñaloza-vázquez and Bender 1998; Rangaswamy and Bender 2000; Smirnova et al. 2002; Wang et al. 1999). Thus, it is possible to predict that the regulation of these cor genes by GacA is significant in the contexts of production of chlorosis symptoms in susceptible interactions as well as elicitation of defense responses in incompatible hosts. As a virulence factor, coronatine induces changes in plant metabolic systems analogous to those induced by plant hormones. Coronatine bears remarkable structural similarities to methyl jasmonate and 12-oxo-phytodienoic acid, prompting the hypothesis that the toxin mimics the octadecanoid signaling molecules of higher plants. How GacA controls corR and $\operatorname{corS}$ remains an open question at this time. Again, our preliminary data suggest that the GacA-mediated regulation of $r s m B$ and rsm Z may be responsible.
The growth rate of the $\mathrm{GacA}_{\mathrm{DC} 3000}{ }^{-}$mutant in $\mathrm{KB}$ medium is very similar to that of DC3000 (Fig. 2). However, in minimal salts plus succinic acid medium, the mutant grows at a somewhat slower rate than the parent, although both attain the same cell density by the onset of stationary phase. Growth of the mutant in planta is reduced compared with that of the parent. These findings raise the possibility that $\mathrm{GacA}_{\mathrm{DC} 3000}{ }^{-}$deficiency may lead to impaired growth in response to change in nutritional content of the apoplast fluid and such reduction in population may be responsible for reduced virulence. While we cannot yet formally rule out that $\mathrm{Gac}_{\mathrm{DC} 3000}$ affects overall metabolic efficiency and, hence, virulence of DC3000, it is more likely that regulation of virulence effectors by $\mathrm{GacA}_{\mathrm{DC} 3000}$ is actually responsible for disease production and the HR induction.

It has been documented that the GacS/GacA system regulates the quorum-sensing signal by positively controlling the biosysthesis of AHL in $P$. aeruginosa, $P$. aureofaciens, and $P$. syringae (Chancey et al. 1999; Dumenyo et al. 1998; Kendra et al. 2000; Kitten et al. 1998; Pessi and Haas 2001; Zhang and Pierson 2001). The quorum-sensing signal controls the $\mathrm{HCN}$ biosynthetic genes (hcnABC) in $P$. aeruginosa (Pessi and Haas 2001) and phenazine antibiotic biosynthesis genes phzXYFABCD in P. aureofaciens (Zhang and Pierson 2001). However, AHL has no effect on protease production in P. aureofaciens (Zhang and Pierson 2001) and various secondary metabolites, extracellular protease, and swarming motility in P. syringae pv. syringae (Dumenyo et al. 1998; Kinscherf and Willis 1999). We have shown that GacA is required for the production of AHL and expression of ahlI and $a h l R$ in DC3000. However, we do not yet know if AHL controls the expression of genes involved in virulence of DC3000 or secondary metabolite production. We have begun searching for AHL-deficient mutants. Transcript profiles in DC3000, its AHL-deficient mutant, and GacA-deficient mutant should allow us to identify the AHLdependent genes, AHL-independent genes, and the regulatory effects of $\mathrm{Gac}_{\mathrm{DC} 3000}$ on these genes.

GacA positively regulates the expression of the sigma factor gene rpoS in $P$. syringae, $P$. fluorescens, E. coli, and Erwinia carotovora (Cui et al. 2001; Kinscherf and Willis 1999; Mukhopadhyay et al. 2000; Whistle et al. 1998). We document here that $\mathrm{GacA}_{\mathrm{DC} 3000}$ controls transcript level of $r p o S$ in DC3000 as well (Fig. 3A). We propose that GacS and GacA control RpoS production and various stress responses in DC3000 as a part of a regulatory cascade (Fig. 6). There is precedence in the literature for similar cascades controlling various traits in different bacteria. For example, in Azotobacter vinlandii (Castañeda et al. 2001), a similar cascade was found to control alginate production as well as gene expression during stationary phase. Likewise, Loper and associates determined that GacS and GacA played a critical role in the expression of rpoS in P. fluorescens and, consequently, had a marked effect on stress response and antifungal metabolite production (Whistler et al. 1998).

GacA is known to affect metabolites and proteins that are produced by bacteria during postexponential growth, presumably when bacteria are exposed to various stresses (Heeb and Haas 2001). How this is brought about is not yet known. However, the following possibilities merit consideration: i) the regulatory effects of GacA on $\operatorname{rpoS}$, which is probably required to cope with various stress conditions; ii) the enhanced activity of GacA, which could depend upon the relative pool size of phosphorylated and dephosphorylated forms of GacA, assuming that the phosphorylated form functions as the transcriptional enhancer; and iii) the stimulation of GacA production during later growth stages and under stress conditions. Our data support the first and the last possibilities. The levels of gacA transcripts are higher during postexponential growth of 
DC3000. More importantly, gacA transcript levels are much higher in IM than in KB. We should note that transfer from KB to IM represents a nutritional shift down as well as exposure to an acidic environment. Both these conditions may trigger stress response in DC3000, activating gacA expression. How gacA is regulated in DC3000 is not yet known. In Erwinia carotovora subsp. carotovora, we have evidence to suggest that FlhCD, master regulators of flagella and exoproteins, positively regulate gacA expression (A. Chatterjee, unpublished data). Although GacA is located at the top of the regulatory hierarchy in DC3000 (Fig. 6), it remains a possibility that another regulator controls gacA expression.

\section{MATERIALS AND METHODS}

\section{Bacterial strains, plasmids, and media.}

Bacterial strains and plasmids are described in Table 1. The wild-type strains were maintained on KB agar. The strains carrying drug markers were maintained on $\mathrm{KB}$ agar containing appropriate antibiotics. Recipes of $\mathrm{KB}$ medium, minimal salts medium, and nutrient gelatin agar (NG) have been described (Chatterjee et al. 1995). CAS agar plate (Schwyn and Neilands 1987) and SWM agar plate (Kinscherf and Willis 1999) were used for testing siderophore and swarming motility, respectively. The IM was made according to Huang and associates (1995). When required, antibiotics were supplemented as follows $(\mu \mathrm{g} / \mathrm{ml})$ : ampicillin, 100 ; kanamycin $(\mathrm{Km}), 50$; spectinomycin, 50; and tetracycline (Tc), 10. Media were solidified by the addition of $1.5 \%$ agar.

\section{DNA techniques.}

Standard procedures were used in the isolation of plasmid and chromosomal DNAs, electroporation, restriction endonuclease digests, gel electrophoresis, and DNA ligation and Southern blot analysis (Sambrook et al. 1989). PCR was performed as described by Liu and associates (1998). The Primera-Gene DNA labeling system and restriction and modifying enzymes were obtained from Promega (Madison, WI, U.S.A.).

\section{Nucleotide sequence analysis.}

All nucleotide sequence data of DC3000 used in this research are obtained from the TIGR website. The homology of DNA and protein sequences of $g a c A_{D C 3000}$ were analyzed by using Blast. Sequence alignment were done using the ExPASy ClustalW program. Motifs search was done using the ExPASy Prositescan program, and default parameters were used.

\section{RNA preparation and}

\section{Northern hybridization experiments.}

Total RNA was extracted according to the method of Aiba and associates (1981) from $P$. syringae strains grown at $28^{\circ} \mathrm{C}$ in $\mathrm{KB}$ medium to Klett values as mentioned in the figure captions or to a Klett value of 100 units and then switched into IM for an additional 2-h incubation.

The concentration of RNA was spectrophotometrically determined and normalized for each sample. Total RNAs (15 to $20 \mu \mathrm{g}$ ) were loaded in each lane as indicated in the figure captions. Representative pictures of ethidium bromide-staining of the denatured agarose gel, indicated by arrows in Figures 1 and 4 , are included to show that equal amounts of total RNA were loaded in each well. The RNA markers $(0.28$ to $6.58 \mathrm{~kb})$ were obtained from Promega.

The probes used in this work were the internal fragments of hopPtoD1, hopPtoD2, hopPtoC, hopPtoF, hopPtoJ, and hopPtoK from pLN4, pLN5, pLN6, pLN7, pLN8, and pLN9 respectively, $c f l$ from pHL2B. hrpL (174 to $307 \mathrm{nt}), h r p R$ (131 to $380 \mathrm{nt}$ ), $h r p S$ (21 to $431 \mathrm{nt}), h r p Z$ (15 to $263 \mathrm{nt}$ ), $\operatorname{hrpC}$ (152 to $393 \mathrm{nt}), \operatorname{gacA}$ (1 to $601 \mathrm{nt}$ ), salA (1 to $597 \mathrm{nt}), \operatorname{rpoN}$ (125 to $364 \mathrm{nt}), \operatorname{avrPtoB}(65$ to $689 \mathrm{nt}), \operatorname{avrPpiB}(127$ to $742 \mathrm{nt})$, hopPmaH ${ }_{\text {Pto }}$ (372 to $707 \mathrm{nt}$ ), rpoS (1 to $999 \mathrm{nt}$ ), rsmZ (1 to 108 $\mathrm{nt}), \operatorname{rsmB}$ (1 to $120 \mathrm{nt}), \operatorname{alg} T$ ( 1 to $585 \mathrm{nt}), \operatorname{ahlI}(51$ to $487 \mathrm{nt})$, $\operatorname{ahlR}(273$ to $519 \mathrm{nt}), \operatorname{tnpA}(138$ to $586 \mathrm{nt}), c f a 8$ (125 to $354 \mathrm{nt})$, cfa9 (133 to $400 \mathrm{nt})$, fadD (266 to $695 \mathrm{nt})$, fliO (1n to $438 \mathrm{nt})$, $\operatorname{algD}$ (91 to $467 \mathrm{nt}), \operatorname{catF}$ (257 to $640 \mathrm{nt}), \operatorname{corS}$ (36 to $523 \mathrm{nt}$ ), corR (1 to $600 \mathrm{nt})$ and cel orf 1 (94 to $654 \mathrm{nt})$, hopPtoM (282 to $692 \mathrm{nt}$ ), and hopPtoN (72 to $404 \mathrm{nt}$ ) DNA probes were PCRamplified from DC3000 chromosomal DNA, and probes were labeled with $\alpha-{ }^{32} \mathrm{P}[\mathrm{dATP}]$ by random-priming, according to the manufacturer's instructions (Promega, Madison, WI, U.S.A.). The $a h l I$ and $a h l R$ genes of DC3000 were identified by searching the homolog of psmI (AF234628_2) and psmR (AF234628_3) genes of $P$. syringae pv. maculicola in DC3000 genomic sequence. Prehybridization $\left(6 \mathrm{~h}\right.$ at $\left.65^{\circ} \mathrm{C}\right)$ and hybridization $\left(18 \mathrm{~h}\right.$ at $\left.65^{\circ} \mathrm{C}\right)$ were performed in hybridization buffer (6× SSC $[1 \times \mathrm{SSC}$ is $0.15 \mathrm{M} \mathrm{NaCl}$ plus $0.015 \mathrm{M}$ sodium citrate], $2 \times$ Denhardt's, $0.1 \%$ sodium dodecyl sulfate [SDS], $100 \mu \mathrm{g}$ of denatured salmon sperm DNA per ml). After hybridization, membranes were washed twice for 20 min each at $65^{\circ} \mathrm{C}$ in $2 \times$ $\mathrm{SSC}, 0.1 \% \mathrm{SDS}$ and, then, for $30 \mathrm{~min}$ at $65^{\circ} \mathrm{C}$ in $0.5 \times \mathrm{SSC}$, $0.1 \%$ SDS and were examined by autoradiography with X-ray film (Kodak, Rochester, NY, U.S.A.).

\section{S1 nuclease protection assay.}

Primer gacAP1 (10 pmol) (5'-CATGCGTGTGATGCCTGT CCGAAC-3'; complementary to the base position -84 to -60 from the translational start codon) was end-labeled by polynucleotide kinase and $\gamma_{-}{ }^{32}$ PATP. The end-labeled probe was amplified by PCR, using labeled gacAP1 and opposing unlabeled primer gacAP2 (5'-TAGGTTGTAGCCGGATCAAT GCTG-3'; corresponding to the base positions -694 to -670 from the translational start codon) and pAKC1111 as template DNA. The conditions of PCR, hybridization, S1 nuclease digestion, and analysis of the products were as described by Liu and associates (1998).

\section{Bioluminescence assay for AHL production.}

DC3000 and its $\mathrm{GacA}_{\mathrm{DC} 3000}{ }^{-}$mutant AC811 were grown in $\mathrm{KB}$ medium at $28^{\circ} \mathrm{C}$ for $20 \mathrm{~h}$, and culture supernatants were harvested for assays by using an E. coli-based bioassay system as described previously (Chatterjee et al. 1995). There is a linear relationship between the quantity of AHL and the emission of bioluminescence expressed as RLU per minute per milliliter.

\section{Cloning of $\operatorname{gacA}_{D C 3000}$.}

The genomic library of DC3000 was transferred into a GacA $^{-}$mutant of Erwinia carotovora subsp. carotovora, AC5056, which does not produce extracellular protease (Cui et al. 2001). Two plasmids that could restore the extracellular protease production in AC5056 on nutrient gelatin agar were selected. Presence of $g a c A_{D C 3000}$ in those plasmids was confirmed by Southern blot analysis by using a PCR-amplified internal fragment of $g a c A_{D C 3000}$ as probe.

\section{Construction of GacA $_{\text {DC3000 }}^{-}$mutant.}

To inactivate the gacA $_{D C 3000}$, Erwinia carotovora subsp. carotovora $\mathrm{GacA}^{-}$strain AC5056 carrying the gacA $_{D C 3000}{ }^{+}$plasmid pAKC1111 was mutagenized with mini-Tn5-Km ${ }^{\mathrm{r}}$. The $\mathrm{Tc}^{\mathrm{r}} \mathrm{Km}^{\mathrm{r}}$ colonies that did not produce extracellular protease were selected, and insertion in GacA was confirmed by Southern blot analysis. The inactivated gacA $_{D C 3000}$ plasmid pAKC1112 was transferred into DC3000. DC3000 carrying pAKC1112 was grown in $\mathrm{KB}$ plus $\mathrm{Km}$ at $28^{\circ} \mathrm{C}$ for $24 \mathrm{~h}$, was diluted 1000 fold into fresh $\mathrm{KB}$ plus $\mathrm{Km}$, and was incubated for an addi- 
tional $24 \mathrm{~h}$. Bacterial cells were then plated on $\mathrm{KB}$ plus $\mathrm{Km}$ agar and were patched on $\mathrm{KB}$ plus $\mathrm{Km}$ and $\mathrm{KB}$ plus $\mathrm{Km}$ and Tc. A $\mathrm{Km}^{\mathrm{r}} \mathrm{Tc}^{\mathrm{s}}$ colony was selected, and the absence of gac $_{D C 3000}$ RNA was confirmed by Northern blot analysis. The location of mini-Tn5-Km insertion was determined by sequence analysis, using pAKC1112 DNA as the template.

\section{Swarming motility, pigment,} and siderophore production tests.

For the swarming motility test, bacterial cells were inoculated onto SWM agar ( $0.4 \%$ agar) and were incubated at $28^{\circ} \mathrm{C}$. Motility of the bacteria was visually examined.

Pigment production was tested on $\mathrm{KB}$ agar, and siderophore production was tested on CSA agar. Bacterial cells were inoculated on $\mathrm{KB}$ or CSA agar and were incubated at $28^{\circ} \mathrm{C}$. Yellow pigment of bacteria was visually examined and the siderophore production was indicated by a clear zone around the colony.

\section{HR and pathogenicity test.}

Bacteria were grown on $\mathrm{KB}$ agar overnight at $28^{\circ} \mathrm{C}$, and cells were suspended in water for HR or pathogenicity tests. The procedures for HR in tobacco leaves were previously published (Cui et al. 1996; Mukherjee et al. 1997). Young, fully expanded third and fourth leaves of about 8-week-old Nicotiana tabacum L. cv. Samsun were used for the HR test. Bacterial cells $\left(5 \times 10^{6}\right.$ or $\left.1 \times 10^{7} \mathrm{CFU} / \mathrm{ml}\right)$ were infiltrated into tobacco leaves as indicated in the figure captions. Pictures were taken $20 \mathrm{~h}$ after infiltration. For the pathogenicity test in Arabidopsis, leaves of 5-week-old plants (A. thaliana cv. Columbia) were infiltrated with bacterial cells $\left(1 \times 10^{6}\right.$ $\mathrm{CFU} / \mathrm{ml}$ ). Pictures were taken four days after inoculation. DC3000 strains were assessed for their ability to cause disease symptoms and multiply in planta by dipping tomato ( $L y$ copersicon esculentum cv. Moneymaker) plants into bacterial suspensions that were adjusted to an optical density at 600 $\mathrm{nm}$ of 0.2 in $10 \mathrm{mM} \mathrm{MgCl} 2$ containing $0.02 \%$ Silwet L-77 (Lehle Seeds, Round Rock, TX, U.S.A.) and were enumerated as previously described (Alfano et al. 2000). Pictures were taken five days after inoculation.

\section{ACKNOWLEDGMENTS}

Our work was supported by the National Science Foundation (grants MCB-9728505 and DBI-0077622), Research Board grant \#99-121, and the Food for the 21st Century program of the University of Missouri. We thank C. Bender for providing plasmid pHL2B, M. Guo for providing constructs encoding effectors, T. Petniki-Ocwieja for testing how the DC3000 $\mathrm{GacA}^{-}$mutant performed on tomato, and G. Stacy for critically reviewing the manuscript.

\section{LITERATURE CITED}

Aarons, S., Abbas, A., Adams, C., Fenton, A., and O'Gara, F. 2000. A regulatory RNA (PrrB RNA) modulates expression of secondary metabolite genes in Pseudomonas fluorescens F113. J. Bacteriol. 182:3913-3919.

Aiba, H., Adhya, S., and de Crombrugghe, B. 1981. Evidence for two functional gal promoters in intact Escherichia coli cells. J. Biol. Chem. 256:11905-11910.

Alfano, J. R., Charkowski, A. O., Deng, W. L., Badel, J. L., PetnickiOcwieja, T., van Dijk, K., and Collmer, A. 2000. The Pseudomonas syringae Hrp pathogenicity island has a tripartite mosaic structure composed of a cluster of type III secretion genes bounded by exchangeable effector and conserved effector loci that contribute to parasitic fitness and pathogenicity in plants. Proc. Natl. Acad. Sci. U.S.A. 97:4856-4861.

Bender, C. L., Alarcón-Chaidez, F., and Gross, D. C. 1999. Pseudomonas syringae phytotoxins: Mode of action, regulation, and biosynthesis by peptide and polyketide synthetases. Microbiol. Mol. Biol. Rev. 63:266-292.
Blumer, C., and Haas, D. 2000. Multicopy suppression of a gacA mutation by the infC operon in Pseudomonas fluorescens CHAO: Competition with the global translational regulator RsmA. FEMS (Fed. Eur. Microbiol. Soc.) Letters 187:53-58.

Blumer, C., Heeb, S., Pessi, G., and Haas, D. 1999. Global GacA-steered control of cyanide and exoprotease production in Pseudomonas fluorescens involves specific ribosome binding sites. Proc. Natl. Acad. Sci. U.S.A. 96:14073-14078.

Boch, J., Joardar, V., Gao, L., Robertson, T. L., Lim, M., and Kunkel, B. N. 2002. Identification of Pseudomonas syringae pv. tomato genes induced during infection of Arabidopsis thaliana. Mol. Microbiol. 44:73-88.

Bretz, J., Losada, L., Lisboa, K., and Hutcheson, S. W. 2002. Lon protease functions as a negative regulator of type III protein secretion in Pseudomonas syringae. Mol. Microbiol. 45:397-409.

Bull, C. T., Duffy, B., Voisard, C., Défago, G., Keel, C., and Haas, D. 2001. Characterization of spontaneous gacS and gacA regulatory mutants of Pseudomonas fluorescens biocontrol strain CHAO. Antonie van Leeuwenhoek International J. Gen. Mol. Microbiol. 79:327-336.

Castañeda, M., Sánchez, J., Moreno, S., Núñez, C., and Espin, G. 2001. The global regulators GacA and sigma (S) form part of a cascade that controls alginate production in Azotobacter vinelandii. J. Bacteriol. 183:6787-6793.

Chancey, S., Wood, D., and Pierson, L. 1999. Two-component transcriptional regulation of $\mathrm{N}$-acyl-homoserine lactone production in Pseudomonas aureofaciens. Appl. Environ. Microbiol. 65:2294-2299.

Chancey, S. T., Wood, D. W., Pierson, E. A., and Pierson, L. S. 2002. Survival of GacS/GacA mutants of the biological control bacterium Pseudomonas aureofaciens 30-84 in the wheat rhizosphere. Appl. Environ. Microbiol. 68:3308-3314.

Chatterjee, A., Cui, Y., Liu, Y., Dumenyo, C. K., and Chatterjee, A. K. 1995. Inactiviation of $r s m A$ leads to overproduction of extracellular pectinases, cellulases, and proteases in Erwinia carotovora subsp. carotovora in the absence of the starvation/cell density sensing signal, $\mathrm{N}$-(3-oxohexanoyl)-L-homoserine lactone. Appl. Environ. Microbiol. 61: 1959-1967.

Chatterjee, A., Valasubramanian, R., Ma, W. L., Vachhani, A. K. Gnanamanickam, S., and Chatterjee, A. K. 1996. Isolation of ant mutants of Pseudomonas fluorescens strain Pf7-14 altered in antibiotic production, cloning of $a n t^{+}$DNA, and evaluation of the role of antibiotic production in the control of blast and sheath blight of rice. Biol. Control 7:185-195

Chatterjee, A., Cui, Y., and Chatterjee, A. K. 2002. Regulation of Erwinia carotovora $h r p L_{E c c}\left(\right.$ sigma- $\left.L_{E c c}\right)$, which encodes an extracytoplasmic function (ECF) subfamily of sigma factor required for expression of the HRP regulon. Mol. Plant-Microbe Interact. 15:971-980.

Collmer, A., Alfano, J. R., Anderson, D. M., Badel, J. L., Deng, W.-L., Fouts, D. E., Rehm, A. H., Rojas, C. M., Schneewind, O., and van Dijk, K. 2000. Hrp (type III) protein secretion and the virulence of Pseudomonas syringae and Erwinia chrysanthemi. Pages 65-70 in: Biology of Plant-Microbe Interactions, Vol. 2. P. J. G. M. de Wit, T. Bisseling, and W. Stiekema, eds. International Society for Molecular Plant-Microbe Interactions, St. Paul, MN, U.S.A.

Collmer, A., Lindeberg, M., Petnicki-Ocwieja, T., Schneider, D. J., and Alfano, J. R. 2002. Genomic mining type III secretion system effectors in Pseudomonas syringae yields new picks for all TTSS prospectors. Trends Microbiol. 10:462-469.

Cui, Y., Chatterjee, A., Liu, Y., Dumenyo, C. K., and Chatterjee, A. K. 1995. Identification of a global repressor gene, rsmA, of Erwinia carotovora subsp. carotovora that controls extracellular enzymes, $\mathrm{N}-(3-$ oxohexanoyl)-L-homoserine lactone, and pathogenicity in soft-rotting Erwinia spp. J. Bacteriol. 177: 5108-5115.

Cui, Y., Madi, L., Mukherjee, A., Dumenyo, C. K., and Chatterjee, A. K. 1996. The RsmA ${ }^{-}$mutants of Erwinia carotovora subsp. carotovora strain Ecc71 overexpress $h r p N_{E c c}$ and elicit a hypersensitive reactionlike response in tobacco leaves. Mol. Plant-Microbe Interact. 9: 565573.

Cui, Y., Chatterjee, A., and Chatterjee, A. K. 2001. Effect of the two-component system comprising GacA and GacS of Erwinia carotovora subsp. carotovora on the production of global regulatory $r s m B$ RNA,

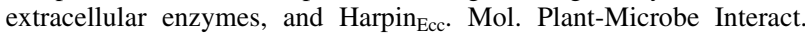
14:516-526.

de Lorenzo, V., Herrero, M., Jakubzik, U., and Timmis, K. N. 1990. MiniTn5 transposon derivatives for insertion mutagenesis, promoter probing, and chromosomal insertionof cloned DNA in gram-negative edubacteria. J. Bacteriol. 172:6568-6572.

Duffy, B. K., and Défago, G. 2000. Controlling instability in gacS-gacA regulatory genes during inoculant production of Pseudomonas fluorescens biocontrol strains. Appl. Environ. Microbiol. 66:3142-3150. 
Dumenyo, C. K., Mukherjee, A., Chun, W., and Chatterjee, A. K. 1998 Genetic and physiological evidence for the production of $N$-acyl homoserine lactones by Pseudomonas syringae pv. syringae and other fluorescent plant pathogenic Pseudomonas species. Euro. J. Plant Pathol. 104:569-582.

Fouts, D. E., Abramovitch, R. B., Alfano, J. R., Baldo, A. M., Buell, C. R., Cartinhour, S., Chatterjee, A. K., D’Ascenzo, M., Gwinn, M. L., Lazarowitz, S. G., Lin, N. C., Martin, G. B. Rehm, A. H., Schneider, K. J., van Dijk, K., Tang, X. Y., and Collmer, A. 2002. Genomewide identification of Pseudomonas syringae pv. tomato DC3000 promoters controlled by the HrpL alternative sigma factor. Proc. Natl. Acad. Sci. U.S.A 99:2275-2280.

Frederick R. D., Ahmad, M., Majerczak, D. R., Arroyo-Rodriguez, A. S Manulis, S., and Coplin, D. L. 2001. Genetic organization of the Pantoea stewartii subsp. stewartii hrp gene cluster and sequence analysis of the $h r p A, h r p C, h r p N$, and wtsE operons. Mol. Plant-Microbe Interact. 14:1213-1222.

Fürste, J. P., Pansegrau, W., Frank, R., Blöcker, H., Scholz, P. Bagdasarian, M, and Lanka, E. 1986. Molecular cloning of the plasmid RP4 primase region in a multi-host-range $\operatorname{tac} P$ peression vector. Gene 48:119-131.

Guttman, D. S., Vinatzer, B. A., Sarkar, S. F., Ranall, M. V., Kettler, G. Greenberg, J. T. 2002. A functional screen for the type III (Hrp) secretome of the plant pathogen Pseudomonas syringae. Science 295:17221726.

Heeb, S., and Haas, D. 2001. Regulatory roles of the GacS/GacA twocomponent system in plant-associated and other gram-negative bacteria. Mol. Plant Microbe Interact. 14:1351-1363.

Heeb, S., Blumer, C., and Haas, D. 2002. Regulatory RNA as mediator in GacA/RsmA-dependent global control of exoproduct formation in Pseudomonas fluorescens CHAO. J. Bacteriol. 184:1046-1056.

Hendrickson, E. L., Guevera, P., and Ausubel, F. M. 2000. The alternative sigma factor RpoN is required for hrp activity in Pseudomonas syringae pv. maculicola and acts at the level of hrpL transcription. J. Bacteriol. 182:3508-3516.

Huang, H.-C., Lin, R.-H., Chang, C.-J. Collmer, A., and Deng, W.-L. 1995. The complete hrp gene cluster of Pseudomonas syringae pv. syringae 61 includes two blocks of genes required for harpin ${ }_{\mathrm{Pss}}$ secretion that are arranged collinearly with Yersinia ysc homologs. Mol. Plant-Microbe Interact. 8:733-746.

Hutcheson, S. W., Bretz, J., Sussan, T., Jin, S., and Pak, K. 2001. Enhancer-binding proteins HrpR and HrpS interact to regulate hrp-encoded type III protein secretion in Pseudomonas syringae strains. J. Bacteriol. 183:5589-5598.

Kendra, R., Griswold, J., and Hamood, A. 2000. The role of quorum sensing in the in vivo virulence of Pseudomonas aeruginosa. Microbes Infect. 2:1721-1731.

Kinscherf, T. G., and Willis, D. K. 1999. Swarming by Pseudomonas syringae $\mathrm{B} 728 \mathrm{a}$ requires $\operatorname{gacS}(\operatorname{lemA})$ and $g a c A$ but not the acylhomoserine lactone biosynthetic gene ahlI, J. Bacteriol. 181:4133-4136.

Kitten, T., Kinscherf, T., McEvoy, J., and Willis, D. 1998. A newly identified regulator is required for virulence and toxin production in Pseudomonas syringae. Mol. Microbiol. 28:917-929.

Laville, J., Voisard, C., Keel, C., Maurhofer, M., Défago, G., and Haas, D. 1992. Global control in Pseudomonas fluorescens mediating antibiotic synthesis and suppression of black root rot of tobacco. Proc. Natl. Acad. Sci. U.S.A. 89:1562-1566.

Liu, Y., Cui, Y., Mukherjee, A., and Chatterjee, A. K. 1998. Characterization of a novel RNA regulator of Erwinia carotovora ssp. carotovora that controls production of extracellular enzymes and secondary metabolites. Mol. Microbiol. 29:219-234.

Lu S.-E., Scholz-Schroeder, B. K., and Gross, D. C. 2002. Characterization of the salA, syrF, and syrG regulatory genes located at the right border of the syringomycin gene cluster of Pseudomonas syringae pv. syringae. Mol. Plant-Microbe Interact. 15:43-53.

Mor H., Manulis, S., Zuck, M., Nizan, R., Coplin, D. L., and Barash, L. 2001. Genetic organization of the hrp gene cluster and $d s p A E / B F$ operon in Erwinia herbicola pv. gypsophilae. Mol. Plant-Microbe Interact. 14:431-436.

Mukherjee, A., Cui, Y., Liu, Y., and Chatterjee, A. K. 1997. Molecular characterization and expression of the Erwinia carotovora $h r p N_{E c c}$ gene, which encodes an elicitor of the hypersensitive reaction. Mol. Plant-Microbe Interact. 10:462-471.

Mukhopadhyay, S., Audia, J. P., Roy, R. N., and Schellhorn, H. E. 2000. Transcriptional induction of the conserved alternative sigma factor RpoS in Escherichia coli is dependent on BarA, a probable two-component regulator. Mol. Microbiol. 37:371-381.

Natsch, A., Keel, C., Pfirter, H. A., Haas, D., and Défago, G. 1994 Contribution of the global regulator gene gacA to persistence and dissemination of Pseudomonas fluorescens biocontrol strain CHA0 introduced into soil microcosms. Appl. Environ. Microbiol. 60:2553-2560

Parkins, M. D., Ceri, H., and Storey, D. G. 2001. Pseudomonas aeruginosa GacA, a factor in multihost virulence, is also essential for biofilm formation. Mol. Microbiol. 40:1215-1226.

Peñaloza-vázquez, A., and Bender, C. L. 1998. Characterization of CorR, a transcriptional activator which is required for biosynthesis of the phytotoxin coronatine. J. Bacteriol. 180:6252-6259.

Pessi, G., and Haas, D. 2001. Dual control of hydrogen cyanide biosynthesis by the global activator GacA in Pseudomonas aeruginosa PAO1. FEMS (Fed. Eur. Microbiol. Soc.) Lett. 200:73-78.

Pessi, G., Williams, F., Hindle, Z., Heurlier, K., Holden, M. T. G., Camara, M., Haas, D., and Williams, P. 2001. The global posttranscriptional regulator RsmA modulates production of virulence determinants and $\mathrm{N}$-acylhomoserine lactones in Pseudomonas aeruginosa. J. Bacteriol. 183: 6676-6683.

Petnicki-Ocwieja, T., Schneider, D. J., Tam, V. C., Chancey, S. T. Shan, L., Jamir, Y., Schechter, L. M., Janes, M. D., Buell, C. R., Tang, X., Collmer, A., and Alfano, J. R. 2002. Genomewide identification of proteins secreted by the Hrp type III protein secretion system of Pseudomonas syringae pv. tomato DC3000. Proc. Natl. Acad. Sci. U.S.A. 99:7652-7657.

Rahme, L. G., Mindrinos, M., and Panopoulos, N. 1991. Plant and environmental sensory signals control the expression of hrp genes in Pseudomonas syringae pv. phaseolicola. J. Bacteriol. 174:34993507.

Rangaswamy, V., and Bender, C. L. 2000. Phosphorylation of CorS and CorR, regulatory proteins that modulate production of the phytotoxin coronatine in Pseudomonas syringae. FEMS (Fed. Eur. Microbiol. Soc.) Lett. 193:8-13.

Rich, J. J., Kinscherf, T. G., Kitten, T., and Willis, D. K. 1994. Genetic evidence that the gacA gene encodes the cognate response regulator for the lemA sensor in Pseudomonas syringae. J. Bacteriol. 176:74687475

Romeo, T. 1998. Global regulation by the small RNA-binding protein CsrA and the non-coding RNA molecule CsrB. Mol. Microbiol. 29:1321-1330.

Saleh, S. S., and Glick, B. R. 2001. Involvement of gacS and $r p o S$ in enhancement of the plant growth-promoting capabilities of Enterobacter cloacae CAL2 and UW4. Can. J. Microbiol. 47:698-705.

Sambrook, J., Fritsch, E. F., and Maniatis, T. 1989. Molecular Cloning: A Laboratory Manual, 2nd ed. Cold Spring Harbor Laboratory Press, Cold Spring Harbor, NY, U.S.A.

Schwyn, B., and Neilands, J. B. 1987. Universal chemical assay for the detection and determination of siderophores. Anal. Biochem. 160:4756.

Smirnova, A. V., Wang, L., Rohde, B., Budde, L., Weingart, H., and Ullrich, M. S. 2002. Control of temperature-responsive synthesis of the phytotoxin coronatine in Pseudomonas syringae by the unconventional two-component system, CorRPS. J. Mol. Microbiol. Biotechnol. 4:191-196.

Ullrich, M., Peñaloza-vázquez, A., Bailey, A. M., and Bender, C. L. 1995. A modified two-component regulatory system is involved in temperature-dependent biosynthesis of the Pseudomonas syringae phytotoxin coronatine. J. Bacteriol. 177:6160-6169.

Wang, L., Bender, C. L., and Ullrich, M. S. 1999. The transcriptional activator CorR is involved in biosynthesis of the phytotoxin coronatine and binds to the $c m a A B T$ promoter region in a temperature-dependent manner. Mol. Gen. Genet. 262:250-260.

Wei, Z. M., and Beer, S. V. 1995. hrpL activites Erwinia amylovora hrp gene transcription and is a member of the ECF subfamily of sigma factors. J. Bacteriol. 177:6201-6210.

Wei Z. M., Kim, J. F., and Beer, S. V. 2000. Regulation of hrp genes and type III protein secretion in Erwinia amylovora by HrpX/HrpY, a novel two-component system, and HrpS. Mol. Plant-Microbe Interact. 13:1251-1262.

Whistler, C. A., Corbell, N. A., Sarniguet, A., Ream, W., and Loper, J. E. 1998. The two-component regulators GacS and GacA influence accumulation of the stationary-phase sigma factor sigmaS and the stress response in Pseudomonas fluorescens Pf-5. J. Bacteriol. 180:6635-6641.

Whistler, C. A., Stockwell, V. O., and Loper, J. E. 2000. Lon protease influences antibiotic production and UV tolerance of Pseudomonas fluorescens Pf-5. Appl. Environ. Microbiol. 66:2718-2725.

Willis, D. K., Hrabak, E. M., Rich, J. J., Barta, T. M., Lindow, S. E., and Panopoulos, N. J. 1990. Isolation and characterization of a Pseudomonas syringae pv. syringae mutant deficient in lesion formation on bean. Mol. Plant-Microbe Interact. 3:149-156.

Willis, D. K., Holmstadt, J. J., and Kinscherf, T. G. 2001. Genetic evidence that loss of virulence associated with gacS or gacA mutations in 
Pseudomonas syringae B728a does not result from effects on alginate production. Appl. Environ. Microbiol. 67:1400-1403.

Windgassen, M., Urban, A., and Jaeger, K.-E. 2000. Rapid gene inactivation in Pseudomonas aeruginosa. FEMS (Fed. Eur. Microbiol. Soc.) Lett. 193:201-205.

Xiao, Y., Heu, S. G., Yi, J., Lu, Y., and Hutcheson, S. W. 1994. Identification of a putative alternate sigma factor and characterization of a multicomponent regulatory cascade controlling the expression of Pseudomonas syringae pv. syringae pss61 hrp and hrmA genes. J. Bacteriol. 176:1025-1036.

Zhang, Z., and Pierson, L. S. 2001. A second quorum-sensing system regulates cell surface properties but not phenazine antibiotic produc- tion in Pseudomonas aureofaciens. Appl. Environ. Microbiol. 67:4305-4315.

Zink, R. T., Kemble, R. J., and Chatterjee, A. K. 1984. Transposon Tn5 mutagenesis in Erwinia carotovora subsp. carotovora and Erwinia carotovora subsp. atroseptica. J. Bacteriol. 157: 809-814.

\section{AUTHOR-RECOMMENDED INTERNET RESOURCES}

The Institute for Genomic Research (TIGR) web site: www.tigr.org The Expert Protein analysis system (ExPASy) website: www.expasy.ch 